\title{
ORIGINAL ARTICLE \\ Can Pteropus giganteus Brünnich, 1782 co-exist in a human dominated landscape? A case study in Pokhara valley, western Nepal
}

\author{
Basant Sharma ${ }^{1,2,3, *}$, Anoj Subedi ${ }^{3}$, Kritagya Gyawali ${ }^{1,3}$, Prashant Ghimire ${ }^{3}$, Bhuwan Singh Bist ${ }^{3}$ \\ Sanjeev Baniya ${ }^{1,2,3}$
}

${ }^{1}$ Bat Friends Pokhara, Nepal.

${ }^{2}$ Nepal Bat Research and

Conservation Union (NeBRCU).

${ }^{3}$ Institute of Forestry (IOF Pokhara), Tribhuvan University, Nepal.

*Corresponding author e-mail: b.s.sharma237@gmail.com

DOI: https://doi.org/10.14709/ BarbJ.11.1.2018.06

Keywords: bamboo harvest, Dendrocalamus strictus, encroachment, housing, Nepal, Pokhara valley, Pteropus giganteus.

received: March, 08th 2018 accepted: July, 21st 2018

\begin{abstract}
Pteropus giganteus Brunnich, 1782 is the largest species of bat found in Nepal. Among the 20 colonies of $P$. giganteus recorded in Nepal, Chinnedanda, in the Pokhara valley, has been one of the most important diurnal roost sites for many decades, hosting a colony with up to 500 individuals. The existence of this species in Chinnedanda is threatened due to habitat encroachment and cutting of preferred roosting trees (Bombax ceiba and Dendrocalamus strictus) by local residents. Here we describe the effect of house construction on the colony and its shift from Chinnedanda to Shanti Banbatika, a nearby (4 km away) alternative roost. Monthly roost count surveys were conducted from July 2016 to December 2017 in order to understand the changes in numbers of roosting bats at both sites. Pearson correlation coefficients were calculated to assess the effect of building construction on the colony in Chinnedanda. Our findings indicate that the effects of building construction on the bats roosting at Chinnedanda became significantly more evident after four months of construction and suggest that the cutting of preferred roosting vegetation (Dendrocalamus strictus) for construction of buildings to use as scaffolding resources was the main factor causing the colony to relocate to Shanti Banbatika. Shanti Banbatika is now the primary roost site for $P$. giganteus in the Pokhara valley. The forest grove at this location should be preserved and human disturbances minimized to maintain it as a suitable roost for $P$. giganteus in future.
\end{abstract}

\section{INTRODUCTION}

Urbanization is a major process of land use change that has considerably transformed habitats and landscapes available to wildlife (Russo \& Ancillotto 2015). The on-going massive growth of urban areas has resulted in the replacement of original habitats in most areas of the world (Baker \& Harris 2007). Many studies have found that urbanization may have detrimental effects to the natural communities including: habitat loss and fragmentation (Scolozzi \& Geneletti 2012) and may influence species distribution, abundance and movements (Tait et al. 2014). Urbanization either leads to species exclusion or behavioral adjustment, from foraging patterns to breeding timing (Lowry et al. 2013). Among other urban species, bats are a highly diverse group of mammals that occur worldwide and several species persist in cities and towns (Jung \& Kalko 2011). Due to the coexistence with human populations in urban landscape, some species may eventually come into conflict with humans over living space and food (Sedhain \& Adhikary 2016), causing impacts such as vegetation damage, risk of disease transmission or different living disturbance such as smell and noise (LópezBaucells et al. 2017). Considering the population growth of humans worldwide and the growing demands for access to land, a greater understanding of the impacts of urbanization on wildlife is urgently needed to provide better conservation strategies for species and their habitats.
Old world fruits bats are members of the family Pteropodidae which is composed of 42 genera and about 182 species worldwide (Simmons 2005, Wilson \& Mittermeier 2009), including 13 species in South Asia (Srinivasulu et al. 2010). Pteropus is one of two genera known as flying foxes and is the most species-rich genus in the family, with about 60 species globally (Simmons 2005) and four species in South Asia, including two that are endemic: Pteropus faunulus and $P$. melanotus (Srinivasulu et al. 2010). Flying foxes mainly forage for fruit and flowers, with some traveling up to $50-100 \mathrm{~km}$ daily to find food (Roberts et al. 2012). Five species of pteropodids are known from Nepal, four of which are relatively widespread: Pteropus giganteus (Brünnich 1782), Rousettus leschenaulti (Desmarest 1820), Cynopterus sphinx (Vahl 1797) and Eonycteris spelaea (Dobson 1871). Sphaerias blanfordi (Thomas 1891) has been recorded only once in Nepal (Leekagul \& McNeely 1977, Acharya et al. 2010).

The Indian flying fox (Pteropus giganteus) is the largest bat found in Nepal (Acharya et al. 2010). It is listed as Least Concern on the IUCN Red List and National Red List although its population is decreasing (IUCN 2008, Jnawali et al. 2011). This species is generally found in large colonies of hundreds to thousands of individuals although sometimes solitary bats or groups of a few individuals may roost near colonies (Jnawali et al. 2011). It prefers to roost in tall canopy trees 
with small trunk diameters of Bombax ceiba, Dalbergia sissoo, Tectona grandis and Eucalyptus camaldulensis near ponds and roadsides (Acharya et al. 2010, Gulraiz et al. 2015). Populations of $P$. giganteus have been greatly reduced due to deforestation, electrocution, and hunting (Ali 2010) as well as human development such as road expansion, building construction, and renovation of temples (Srinivasulu \& Srinivasulu 2004, Molur et al. 2008, Gaikwad et al. 2012).

The Pokhara valley is a major hotspot for bat species richness in Nepal, hosting 17 of the 53 species of bats recorded in the country (Giri 2009, Acharya et al. 2010, Thapa 2010). The valley has supported one of Nepal's most important roosts of $P$. giganteus at Chinnedanda for many decades, with up to 500 individuals present in 2011 (Bista 2011). This is the only known colony in the valley and is one of 20 colonies existing in the nation (Giri 2009, Acharya 2015, Sharma 2016). However, this roost site has become more threatened in recent years due to human encroachment, habitat destruction, and the cutting of preferred roost trees, Bombax ceiba by local residents to prepare a land for construction of houses (Adhikari 2009, Bista 2011). After the harvest of half of the bats' roost trees from 2011 to 2016, most of the colony were found to roost in Dendrocalamus strictus, a species of bamboo (Adhikari 2009, Bista 2011, Sharma 2016). Then in early 2016, half of the colony moved to a new roost site at Shanti Banbatika $4 \mathrm{~km}$ from Chinnedanda (Sharma 2016). This is the first record of colony establishment in Shanti Banbatika. In this paper, we describe the recent size of this colony, the effect of housing construction near the roost at Chinnedanda and investigate the probable causes of the colony's displacement to a new location.

\section{MATERIALS AND METHODS}

\section{Study site}

The Pokhara valley in western Nepal covers an area of $123 \mathrm{sq} \mathrm{km}$ and occurs within Kaski district. The valley has a humid sub-tropical monsoonal climate with hot and wet summers and cold and fairly dry winters. Average daily temperatures range between $25^{\circ}$ and $33^{\circ} \mathrm{C}$ in summer and between $-2^{\circ} \mathrm{C}$ and $15^{\circ} \mathrm{C}$ in winter (Kansakar et al. 2004), with a mean annual precipitation of $<3000 \mathrm{~mm}$ (Khanal 1995). Altitude is approximately $849 \mathrm{~m}$ a.s.I.

The two colony roosts described in this study are located in Chinnedanda $\left(28^{\circ} 10^{\prime} 53.4^{\prime \prime} \mathrm{N}, 84^{\circ} 00^{\prime} 42.5^{\prime \prime} \mathrm{E}\right)$ and Shanti Banbatika (28 $\left.12^{\prime} 44^{\prime \prime} \mathrm{N}, 83^{\circ} 59^{\prime} 33^{\prime \prime} \mathrm{E}\right)$ in the Pokhara valley (Fig. 1). Chinnedanda is dominated by agricultural farms, but is becoming increasingly urbanized with expanded human settlement and roads. Bombax ceiba, Dendrocalamus strictus, Ficus religiosia and Morus alba comprise the prominent vegetation scattered near the roost. Shanti Banbatika occurs on a small secluded tract of land ( 15ha) belonging to the Institute of Forestry (IOF), Tribhuvan University, and is surrounded by an urbanized area. The trees Diploknema butyraceae, Osmanthus sauvis, Prunus cerasoides, Dalbergia sisoo and Bombax ceiba form a grove of forest covering part of this site.

\section{Methods}

From July 2016 to December 2017, we conducted monthly roost surveys between 2:00 PM and 4:00 PM on every first Saturday at both roost sites to count the numbers of $P$. giganteus present. Following the direct roost count

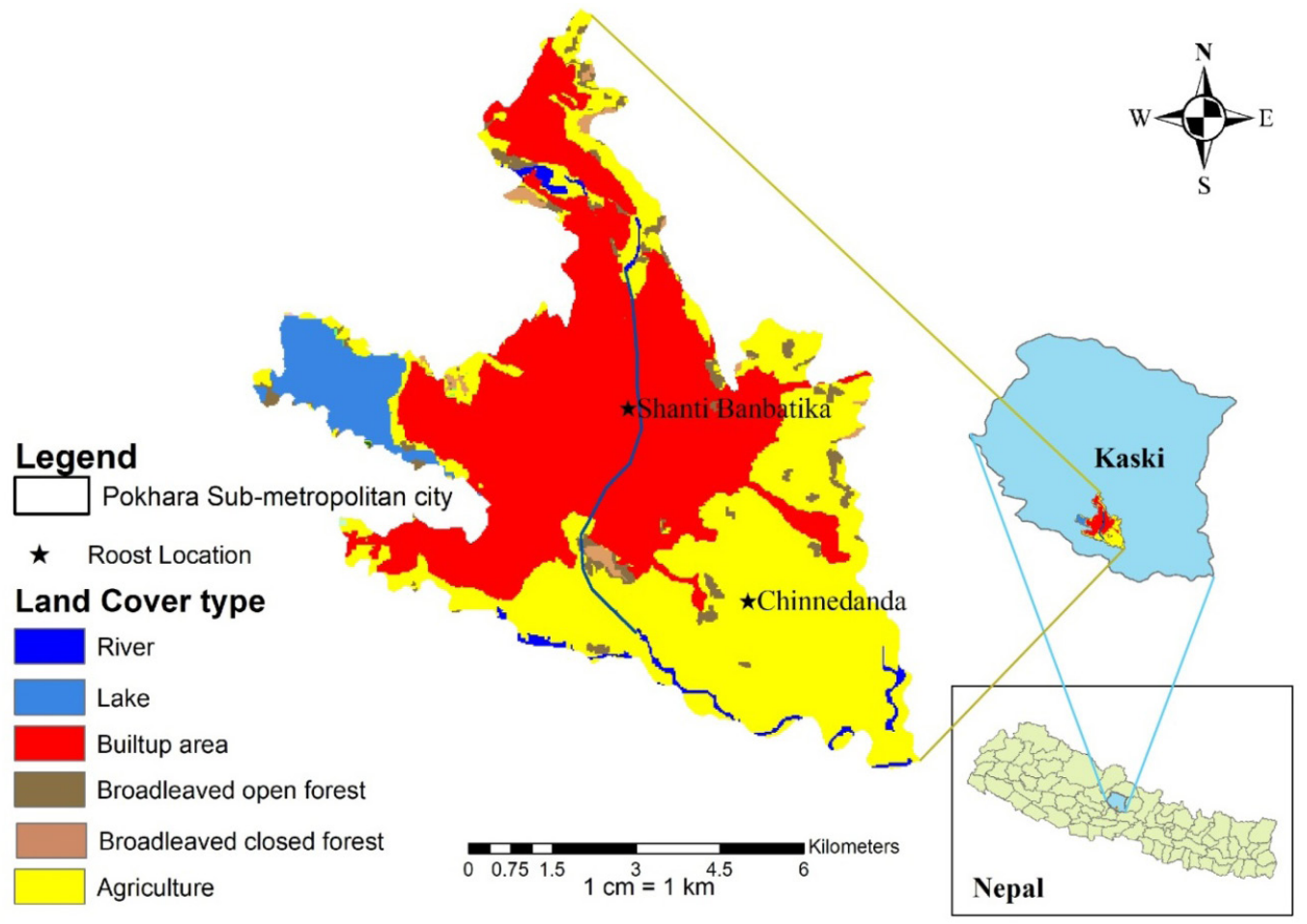

Fig. 1- Map of the study area in the Pokhara Valley, Nepal. Source: Bajracharya (2013) Land cover of Nepal 2010: ICIMOD, created using Arc GIS 10.3.1 by Milan Budha. 
method of Kunz et al. (1996), we recorded the total numbers of bats roosting on tree and bamboo branches with the aid of tally counters and binoculars (Bushnell 8x42). Additionally, numbers and species of trees and bamboo used by roosting bats and numbers of new houses/buildings being built within a 200-m radius of the centre of the colony were counted each month at Chinnedanda. Distances between these new houses/buildings to the edge of the colony were also measured.

We reviewed published and unpublished literature (e.g., relevant articles and theses) to obtain baseline information about the characteristics of the colony and changes to the study area.

To assess the influence of building construction on the colony at Chinnedanda Pearson correlation coefficients were calculated between the numbers of buildings/houses built each month and the resulting difference in colony size. The difference in colony size was assessed as the difference between the colony size during the survey and the colony size detected the five following months. We assumed that the effect would be most noticeable during five months following the start of the building construction, since this is the time typically required to construct a house in Pokhara valley. Linear regression was then fitted and its $R^{2}$ values compared in all five scenarios.

We also conducted interviews of local villagers living near the roost at Chinnedanda in January 2017 using a structured questionnaire (Table S2). Fifty local villagers of ages 25 to 55 years old were randomly selected for the interviews, including builders, workers, house owners, and women. Interview topics focused on $P$. giganteus and the impacts of housing construction activities on the bats.

\section{RESULTS}

At the beginning of our study (July 2016), we found substantially smaller numbers of bats (129 individuals) using the Chinnendanda roost compared to the colony size reported in 2011, as well as a decrease in the number of preferred roost trees at the site (Table S1, Fig. 2 \& 3). During the same survey, we recorded 34 bats at Shanti Banbatika. Bat numbers at Chinnedanda decreased to just 44 bats by December 2016, coinciding with a rapid increase in housing construction (Table S1, Fig. 2). During 2017, this site was either unoccupied or held $\leq 30$ bats (Fig. 5). In contrast, roost size at Shanti Banbatika grew rapidly to 217 bats from September to December 2016, gradually declined to 112 bats by July 2017, and increased substantially again during September and October 2017, reaching a peak of 288 individuals (Table S1, Fig. 2 \& 4). Colony size at the two roosts combined averaged 220 bats during the study, with a peak count of 290 bats in October 2016.

Fifteen new houses were built near the roost at Chinnedanda during the study period. These were constructed an average of $59.5 \mathrm{~m}$ from the edge of the roost, including three built $\leq 10 \mathrm{~m}$ from the roost edge (the closest was $2 \mathrm{~m}$ ) at the same time in October 2016 (Table S1).
Linear regression lines between numbers of houses built and the difference in colony size detected in following months always indicated negative correlation suggesting a detrimental effect due to construction activities (Fig. 6). Values of $R^{2}$ varied substantially depending on the number of months considered in the regression, with the minimum (0.16) observed when only the first month was chosen, and the maximum (0.56) when the following four months were included. $R^{2}$ remained nearly equal whether three $(0.39)$ or five (0.40) months were considered (Fig. 6).

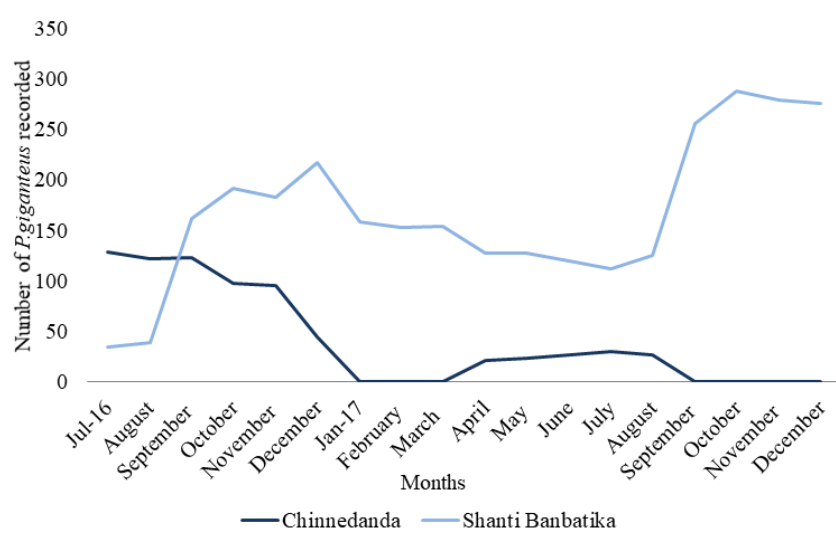

Fig. 2 - Numbers of Pteropus giganteus at the Chinnedanda and Shanti Banbatika roosts during this study.

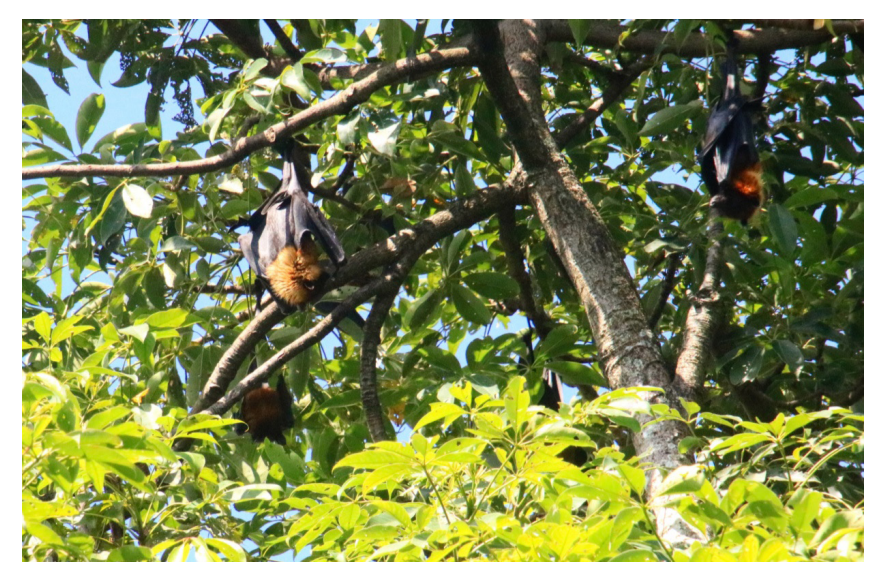

Fig. 3 - Pteropus giganteus roosting in Bombax ceiba at Chinnedanda in July 2016. Credit: Basant Sharma

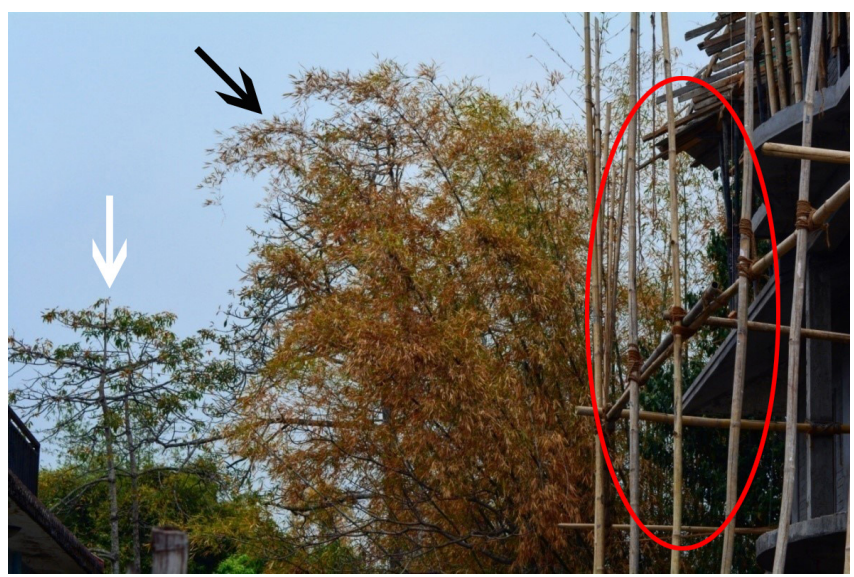

Fig. 4 - Using bamboo as scaffolding (red circle) near the bat roost at Chinnedanda in January 2017: Dendrocalamus strictus (black arrow) and Bombax ceiba (white arrow) Credit: Basant Sharma 

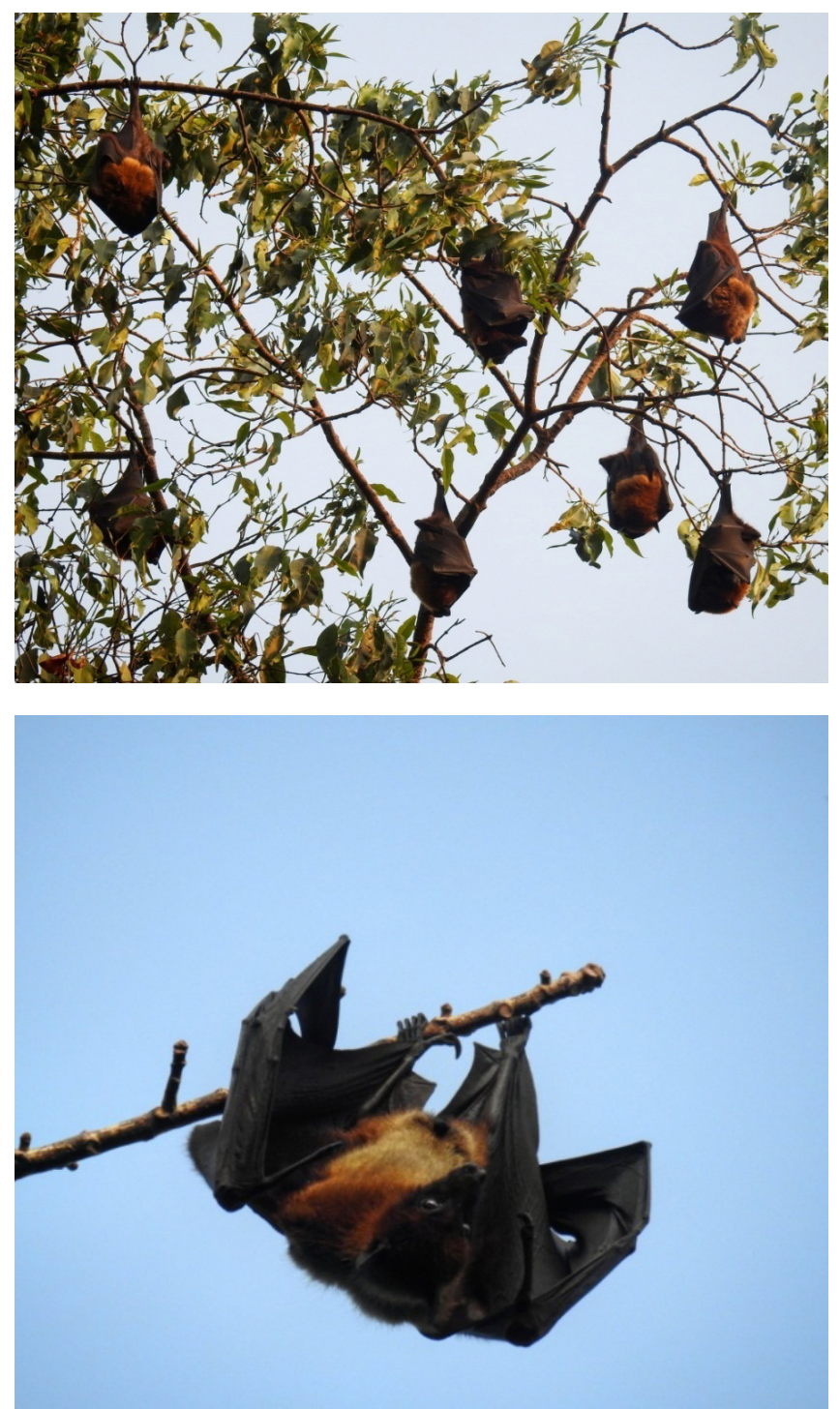

Fig. 5 - Pteropus giganteus roosting in Osmanthus sauvis (up) and Bombax ceiba (down) at Shanti banbatika in January, 2017 Credit: Basant Sharma
Of the 50 respondents, $14 \%$ were classified as builders/ contractors, $32 \%$ as workers, $30 \%$ as house owners and $24 \%$ as housewives; $60 \%$ of the total were male. Ages of respondents were $25-35$ years old (50\%), 35-45 years old (30\%) and $45-55$ years old (20\%). A total of $80 \%$ of the respondents believed that colony size at Chinnedanda was generally decreasing compared to previous years, whereas $8 \%$ thought it was stable, $2 \%$ believed it was increasing, and $10 \%$ were unaware of the colony. Regarding the cutting of roost vegetation, $72 \%$ of the respondents believed it was appropriate to cut down and use Dendrocalamus strictus as scaffolding for building construction, whereas $12 \%$ thought the vegetation should be preserved and $16 \%$ had no opinion. Forty-two percent of respondents had lived in Chinnedanda for more than 10 years, $24 \%$ for 1 to 10 years, $14 \%$ for less than 1 year and 20\% were not residents (e.g., builders/ contractors and workers).

\section{DISCUSSION}

The combined numbers of $P$. giganteus roosting at Shanti Banbatika and Chinnedanda during our study ranged from 142 to 290 bats, representing a decline of about 42 to 72 percent in the size of the full colony since 2011. Furthermore, the roost at Chinnedanda, which had been occupied for many years, was no longer in use by the end of our study period. This roost suffered from two main problems: (1) the cutting of preferred roosting trees (Bombax ceiba) by locals (Adhikari 2009) and (2) the construction of houses near the colony, which further reduced the availability of preferred roosting trees (Bista 2011). Due to lack of preferred roosting trees the majority of population switched to roosting in clumps of bamboos, which appeared to offer a satisfactory alternative over B. ceiba (Bista 2011, Adhikari 2009). However, much of those bamboos were then harvested and used as scaffolding during building construction near the roost. Thus, a decline in roosting vegetation likely displaced the colony from this site.

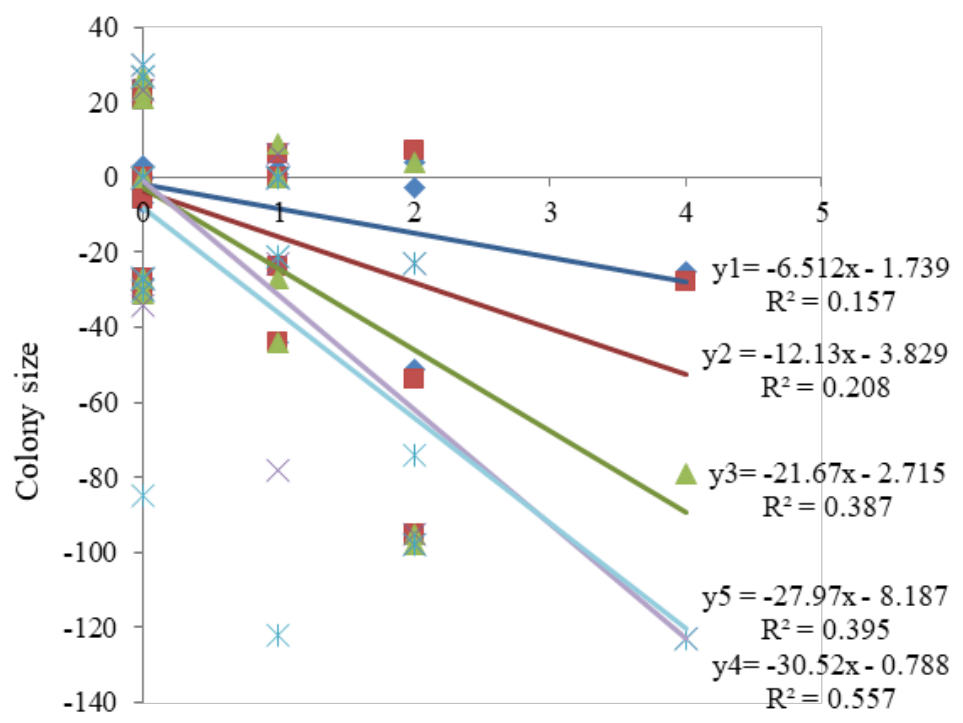

Difference with the next
month

Difference with the next 2 months

$\Delta$ Difference with the next 3 months

$\times$ Difference with the next 4 months

$\nVdash$ Difference with the next 5 months

Number of houses/buildings being built

Fig. 6 - Scatter plot representing fitting linear regression lines between the number of houses/building being built and the difference in colony size in following one to five months in Chinnedanda. 
Construction of houses and buildings up to three stories high are usually completed within five months in the Pohkara valley. This includes one to two months for excavation of the ground and establishment of the foundation, and two to three months to complete the rest of the structure. Construction requires the use of scaffolding made either of long bamboo poles or metal steels to elevate the building structure. Because of the easy accessibility, wide distribution and low cost of bamboo, it is one of the major scaffolding resources used in Pokhara valley (Sapkota 2010). Generally, during the construction of stories matured bamboos (from the bat roost as well as non-roost clumps) were harvested and used as scaffolding. During our survey with residents, we found that most people believed that locally harvested bamboo was preferable over the use of exported bamboo poles and metal steel, despite the fact that most of them were aware of the bat population decrease.

Our findings indicate that the effects of building construction on the bats roosting at Chinnedanda became significantly more evident after four months of construction suggesting that the effects of those activities take several months to reach their maximum impact on the colony size. Pokhara International Airport is under construction in Pokhara and is located $300 \mathrm{~m}$ north from the roost. However, personal observations indicate that the construction of the airport nearby the bat roost and various types of disturbances associated with housing construction (close human presence, noise, and dust) apparently did not affect the bats.

During our study, Shanti Banbatika became the colony's primary year-round roosting site, with numbers peaking at 217 bats in December 2016 and 288 bats in October 2017, which are the highest annual counts ever recorded at this location. Although Shanti Banbatika previously functioned as a foraging site for $P$. giganteus (Bista 2011), it was not used as a diurnal roost until early 2016 (Sharma 2016). The colony's switch to this location is likely related to its better availability of roosting vegetation and possibly lower levels of human disturbance than in Chinnedanda.

There has been increase in urbanization across the Pokhara (Rimal 2011). The urban growth rate between 2010 and 2015 was of $5.21 \%$ (UNDESA 2014). The city has experienced rapid changes during this time as most of the agriculture lands were prioritized for either residential or commercial purposes. The effect of this alteration can be seen in Chinnedanda, which was previously covered mostly with agriculture lands, but it is currently crowded with hundreds of buildings and roads with few open spaces and limited agricultural areas remaining. These changes have had a negative impact on the $P$. giganteus colony, and together with the roosting vegetation reduction, they have caused its decline in size and shift to a new roost at Shanti Banbatika.

During our study, building construction activities were extremely high near the roost at Chinnedanda. Ten houses were built during the first six months of the study, including three built less than ten meters from roost edge. Numbers of roosting bats at the site fell dramatically (66\%) during this period, followed by the complete abandonment of the roost or presence of small numbers of roosting bats during the remainder of the study period. To our knowledge, this roost has never been previously unoccupied. Observations at Chinnedanda before and during our study indicate that colonies of $P$. giganteus at traditional roosting sites can tolerate some limited human disturbance. However, as we noted, excessive destruction of roosting vegetation can eventually result in roost desertion. Although the extent to which $P$. giganteus is resilient to anthropogenic stresses remains unexplored, we believe that the roost at Chinnedanda could be permanently abandoned in the future if a lack of sufficient roosting vegetation continues.

The combined population of $P$. giganteus in Chinnedanda and Shanti Banbatika increased from September to December in both study years, suggesting that the resident flying fox population in the Pokhara valley may be supplemented by migratory individuals. Other studies have shown that colony size of $P$. giganteus usually does not remain constant throughout the year (e.g., Bates \& Harrison 1997). Acharya (2008) recorded seasonal variation in colony size in Nepal's Kathmandu valley and, similar to our study, noted increasing numbers during autumn (after the monsoon). Some flying fox species are known to travel relatively long distances in a few days (Fleming \& Eby 2003). Long-distance movements, including annual migration, provide access to widely spaced and temporally variable food resources, as well as the opportunity to use different areas for roosting and feeding (Roberts et al. 2012). During autumn in Nepal, areas of lower elevation (e.g., the country's Terai region) may offer limited food resources for $P$. giganteus, which may compel the bats to move to higher nearby elevations or to more distant regions such as India, Pakistan and Bangladesh. Seasonal movement patterns have not yet been examined for $P$. giganteus and deserve further study.

The year-round presence of $P$. giganteus at Shanti Banbatika during our study and the small distance $(4 \mathrm{~km})$ between this site and Chinnedanda indicate that the occupation of Shanti Banbatika is not related to seasonal factors such as food availability and maternity care. Shanti Banbatika now appears to be the primary diurnal roost for $P$. giganteus in the Pokhara valley, with peak numbers at times reaching nearly 300 bats comprised of both yearround residents and migratory individuals. It is important that the grove of trees at this site be preserved and human disturbance minimized to maintain the site as a suitable roost for $P$. giganteus. We also recommend continued monitoring of the colony and documentation of current habitat conditions at the site so that any future changes in forest structure can be more easily recognized.

Populations of $P$. giganteus and their habitat are increasingly threatened (Jnawali et al. 2011), not only in the Pokhara valley but across much of the species' distribution (Acharya et al. 2010). Hunting and habitat modification are two of the major flying fox-human conflicts in Nepal. Hunting $P$. giganteus for meat in Jhapa, Morang and Sunsari districts (eastern Nepal), Rautahat and Bhaktapur districts (central Nepal), and Rupandehi, Dang and Kanchanpur districts (western Nepal), and widespread habitat modification in the country currently exert high pressure on this species (Acharya 2015). The government of Nepal lists $P$. giganteus as Least Concern, but if intensive hunting and rapid habitat 
modification continue at present rates, the species will likely need to be uplisted to a higher threatened category in the future. Appropriate guidelines and public awareness must be formulated to minimize hunting pressure, whereas proper management strategies must be launched to lower anthropogenic pressures on habitat. Further educational and communication effort is still essential to achieve good conservation practices, especially considering the results of our interviews in which, although most of the respondents were aware of the bat population decline, only $12 \%$ were in favor of preserving the native vegetation. This case study not only illustrates the problems facing $P$. giganteus in the Pokhara valley, but also shows that increasing anthropogenic pressure can negatively impact the habitat and behavior of other wild species in Nepal.

\section{ACKNOWLEDGEMENT}

We express our heartfelt gratitude and appreciation to Adrià López-Baucells for his consistent encouragement, valuable suggestions and guidelines for publication of this paper. We also thank Gary Wiles and two anonymous reviewers for their comments, which greatly improved the manuscript. We are grateful to Dr. Pushpa Raj Acharya, research officer of Nepal Academics of Science and Technology (NAST) and Chairperson of Nepal Bat Research and Conservation Union (NeBRCU) for his ongoing encouragement and professional guidance in field research. We express our sincere thanks to key members of "Bat friend Pokhara" for their technical and material support during field visits; Milan Budha for creating the map of study area; and Bandana Subedi, Sudha Ghimire, Shristee Panthi, Sunita Kunwar, Barsha Tripathi, Ambika Regmi, Anisha Neupane, Kamana Pathak and the Shirish guys for their assistance in the field.

\section{REFERENCES}

ACHARYA, P.R. (2008). Status and Distribution of Indian Flying Fox in Kathmandu Valley, Nepal. CCINSA Newsletter. 9(1):10-11.

ACHARYA, P.R. (2015, February 15). Conservation Initiatives for Fruit Bats in Nepal. Final report submitted to Rufford Foundation.

ACHARYA, P.R., ADHIKARI, H., DAHAL, S., THAPA, A. \& THAPA, S. (2010). Bats of Nepal-a field guide. ed.: Small Mammals Conservation and Research Foundation (SMCRF), Kantimarga, New Baneshwor, Kathmandu, Nepal. 116 pp.

ADHIKARI, H. (2011). Species richness, distribution, and threats of bats in Palpa and Kaski District of western Nepal. Small Mammal Mail, p. 1-24.

ALI, A. (2010). Population trend and conservation status of Indian Flying fox Pteropus giganteus Brunnich, 1782 (Chiroptera: Pteropodidae) in western Assam. The Ecoscan. 4(4):311-312.
BAKER, P.J. \& HARRIS, S. (2007). Urban mammals: what does the future hold? An analysis of the factors affecting patterns of use of residential gardens in Great Britain. Mammal Review, 37:297-315. http://dx.doi. org/10.1111/ j.1365-2907.2007.00102.x

BATES, P. \& HARRISON, D. (1997). Pteropus giganteus. In: Bats of the Indian Sub-continent. ed.: Harrison Zoological Museum. Harrison, United Kingdom, p.123-258.

BISTA, M. (2011). Status of Indian Flying Fox (Pteropus giganteus) in Pokhara valley. Institute of forestry (IOF), Pokhara, Nepal. Tribhuvan University.

FLEMING, T.H. \& EBY, P. (2003). Pteropus giganteus. In: Ecology of bat migration. ed.: Fleming, T.H., Eby, P., University of Chicago Press, Chicago, USA, p.156-208.

GAIKWAD, M.C., NARWADE, S.S., FARTADE, K.M. \& KORAD, V.S. (2012). A review of the distribution of bats in Southwestern Region of Deccan, Maharashtra-India and conservation recommendations. Taprobanica, 4(1):2736.

GIRI, B.K. (2009). Habitat suitability mapping and species identification of chiroptera: A case study from Kaski district, Nepal. Institute of Forestry (IOF), Pokhara, Nepal. Tribhuvan University.

GULRAIZ, T.L., JAVID, A., MAHMOOD-UL-HASSAN, M., MAQBOOL, A., ASHRAF, S., HUSSAIN, M. \& DAUD, S. (2015). Roost characteristics and habitat preferences of Indian flying fox (Pteropus giganteus) in urban areas of Lahore, Pakistan. Turkish Journal of Zoology, 39(3):388394.

JNAWALI, S.R., BARAL, H.S., LEE, S., SUBEDI, N., ACHARYA, K.P., UPADHYAY, G.P., PANDEY, M., SHRESTHA, R., JOSHI, D., LAMICHANE, B.R., GRIFFITHS, J., KHATIWODA, A. \& AMIN, R. (2011). The Status of Nepal's Mammals: The National Red List Series. Department of National Parks and Wildlife Conservation (DNPWC), Kathmandu, Nepal. p. 214.

JUNG, K. \& KALKO, E.K.V. (2011). Adaptability and vulnerability of high flying Neotropical aerial insectivorous bats to urbanization. Diversity and Distributions, 17(2):262-274. https://doi.org/10.1111/j.1472-4642.2010.00738.x

KANSAKAR., SUNIL, R., HANNAH., DAVID, M., GERRAD., JOHN., \& REES, G. (2004). Spatial pattern in the precipitation regime of Nepal. International Journal of Climatology, 24(13):1645-1659. https://doi. org/10.1002/joc.1098

KHANAL, N.R. (1995). The 1993 Extreme Event in Nepal and Its Consequences. Paper Presented at International Himalayan/Tibetan Plateau Paleoclimate Workshop, 2-7 April, Kathmandu. 
KUNZ, T.H., THOMAS, D.W., RICHARDS, G.C., TIDEMANN, C.R., PIERSON, E.D. \& RACEY, P.A. (1996). Observational techniques for bats. In: Measuring and Monitoring Biological Diversity, Standard Methods for Mammals. ed.: Heyer, W. R., Donnelly, M. A., McDiarmid, R.W., hayek, L.A.C., Foster, M.S., Smithsonian Press, p.105-114.

LEROY, E.M., KUMULUNGUI, B., POURRUT, X., ROUQUET, P., HASSANIN, A., YABA, P., DELICAT, A., PAWESKA, J.T., GONZALEZ, J. \& SWANEPOEL, R. (2005). Fruit bats as reservoirs of Ebola virus. Nature, 438:575-576. https:// doi.org/10.1038/438575a

LOPEZ-BAUCELLS, A., ROCHA, R., ANDRIATAFIKA, Z., TOJOSOA, T., KEMP, J., FORBES, K. \& CABEZA, M. (2017). Roost selection by synanthropic bats in rural Madagascar: what makes non-traditional structures so tempting? Hystrix, 28(1): 28-35. https://doi.org/10.4404/ hystrix-28.1-12046

MOLUR, S., SRINIVASILU, C., BATES, P. \& FRANSIS, C. (2008). Pteropus giganteus. The IUCN Red List of Threatened Species 2008:e.T18725A8511108. Downloaded on 06 March 2018.

RIMAL, B. (2011). Urban Growth and Land use/Land cover Change of Pokhara Sub-Metropolitan City, Nepal. Journal of Theoritical \& Applied information Technology, 26(2).

ROBERTS, B.J., CATTERALL, C.P., EBY, P. \& KANOWSKI, J. (2012). Long-distance and frequent movements of the Flying-Fox Pteropus poliocephalus: Implications for Management. PLOS ONE, 7(8):e42532. https://doi. org/10.1371/journal.pone.0042532

RUSSO, D. \& ANCILLOTTO, L. (2015). Sensitivity of bats to urbanization: A review. Mammalian Biology, 80(3):205215. http://dx.doi.org/10.1016/i.mambio.2014.10.003

SAPKOTA, P. (2010). An Assessment of Resources and Harvesting Practices of Natural Bamboos in Sardikhola VDC, Kaski, Nepal. Institute of Forestry (IOF), Pokhara, Nepal. Tribhuvan University.
SCOLOZZI, R. \& GENELETTI, D. (2012). A multi-scale qualitative approach to assess the impact of urbanization on natural habitats and their connectivity. Environmental Impact Assessment Review, 36:9-22. http://dx.doi. org/10.1016/j.eiar.2012.03.001.

SHARMA, B. (2016). Diet Analysis of Indian Flying Fox in Subtropical Mid hill of Nepal. Institute of Forestry (IOF), Pokhara, Nepal. Tribhuvan University.

SRINIVASULU, C., RACEY, P.A. \& MISTRY, S. (2010). A key to the bats (Mammalia: Chiroptera) of South Asia. Journal of Threatened Taxa, 2(7):1001-1076. http://dx.doi. org/10.11609/JoTT.o2352.1001-76

SRINIVASULU, C. \& SRINIVASULU, B. (2004). Highway development affects the populationl of the indian flying fox Pteropus giganteus (Brunnich, 1782). Zoos' Print Journal. 19(1):1329.

SIMMONS, N.B. (2005). Order Chiroptera. In: Mammal Species of the World: A Taxonomic and Geographic Reference. ed.: The Johns Hopkins University Press, Baltimore, USA, p.312-365.

TAIT, J., PEROTTO-BALDIVIESO, H.L., McKEOWN, A. \& WESTCOTT, D.A. (2014). Are flying-foxes coming to town? Urbanisation of the spectacled flying-fox (Pteropus conspicillatus) in Australia. PLoS ONE. 9(10):e109810. https://doi.org/10.1371/journal.pone.0109810

THAPA, S. (2010). An Updated Checklist of valid bat species of Nepal. Small Mammal Mail - Bi-Annual Newsletter of CCINSA \& RISCINSA, 2 (1): 16-17.

UNDESA. (2014). World Urbanization Prospects: 2014 Revision. New York: United Nations Department of Economic and Social Affairs, 28 pp.

WILSON, D.E. \& MITTERMEIER, R.A. (2009). Handbook of the Mammals of the World. Eds. Lynx. Barcelona, Spain. $727 \mathrm{pp}$. 